\title{
Fingerprinting of Lab Isolated From Silage, Water, Raw Milk, Starter Culture and Minas Artisanal Cheese from the Campo Das Vertentes Region, Brazil
}

\author{
Felipe Machado de Sant Anna ${ }^{1 *}$ and Leonardo Borges Acurcio ${ }^{2}$ \\ ${ }^{1}$ Departamento de Tecnologia e Inspeção de Produtos de Origem Animal, Escola de Veterinária, Universidade Federal de Minas Gerais, Belo Horizonte
} $M G$, Brazil

${ }^{2}$ Departamento de Microbiologia, Instituto de Ciências Biológicas, Universidade Federal de Minas Gerais, Belo Horizonte, MG, Brazil

Submission: February 02, 2018; Published: April 06, 2018

*Corresponding author: Felipe Machado de Sant Anna, Universidade Federal de Minas Gerais, Campus Pampulha, Av Antônio Carlos, 6627, 31270 901, Belo Horizonte, MG, Brazil, Email: vetfelipem@gmail.com

Abstract

The aim of this study was to stablish phylogenetic relations of LAB isolated from water, silage, milk, endogenous starter culture and Minas artisanal cheese from Campo das Vertentes region. Eighty-eight Gram positive, catalase negative samples were submitted to 16-23S rDNA reaction, identifying 36 samples as belonging to Lactobacillus/Pediococcus genus. The $16 \mathrm{~S}$ rRNA sequencing identified five species: Lactobacillus plantarum, L. paracasei, L. brevis, L. rhamnosus and Pediococcus acidilactici. The rep-PCR (GTG)5 fingerprinting showed predominance of $L$. plantarum (75.7\%) in all sources, followed by L. brevis (9.1\%), L. paracasei (6.1\%), P. acidilactici (6.1\%) and L. rhamnosus (3\%).

Keywords : Milk analysis; Cattle; Reproduction; Urea nitrogen

Abbreviations : CAPES: Coordenação de Aperfeiçoamento de Pessoal de Nível Superior; FAPEMIG: Fundação de Amparo à Pesquisa de Minas Gerais; LAB: Lactic acid bacteria; ITS: Internal transcript spacer; UPGMA: Unweighted Pair Group with Arithmetic Mean

\section{Introduction}

Minas Gerais State is the largest cheese producer in Brazil. There are some traditional regions that produce Minas artisanal cheese, such as Campo das Vertentes. Lactic acid bacteria (LAB) are commonly found in milk and endogenous starter culture used for this type of cheese making [1]. Those LAB are partially responsible for the development of typical sensory characteristics and may act like natural inhibitors of undesirable microorganisms in chesses.

\section{Material and Methods}

\section{Sample acquisition}

Samples of silage, water, raw milk, endogenous starter culture and Minas artisanal cheeses (at 0, 7, 14, 21, 28 and 60 days of ripening) were collected from six dairy farms - three certified dairy farms (A, B, C) and three non-certified dairy farms (D, E, F) located in the Campo das Vertentes region.

\section{Isolation, gram staining and catalase test}

Each sample was diluted and spread onto M17 and MRS media (Difco Laboratories, Detroit, Michigan, USA). Plates were incubated under aerobiosis at $37^{\circ} \mathrm{C}$ for $48 \mathrm{~h}[2,3]$. Isolation, Gram staining and catalase test were performed according to Mac Faddin [4] and Standard I D F [2].

\section{DNA extraction}

Pre-treatment of bacterial cells was performed according to Castro et al. [1]. The total DNA from each sample was extracted with the Wizard SV Genomic DNA Purification System (Promega Corporation, Madison, Wisconsin, USA), following manufacturer's instructions.

\section{S-23S ITS amplification}

Genus identification was performed by amplification of the intergenic spacer region from $16 \mathrm{~S}$-23S genes. Internal transcript spacer 1 (ITS 1) was assessed by primers 16-1 and 23-1B. Methodology was performed according to Tilsala, Timisjarvi e Alatossava [5].

\section{(GTG)5 rep-PCR finger printing}

Genotypic differentiation amongst samples was performed in accordance to Gevers, Huys and Swings (2001). rep-PCR was performed using the (GTG)5 PCR as primer. DNA band profiles obtained by the PCR reaction were analyzed in the BioNumerics v6.5 (Applied Maths, Kortrijk, Belgium). Genetic similarity values were calculated by Pearson correlation and used to build a dendrogram by UPGMA (Unweighted Pair Group with Arithmetic Mean). 


\section{S rRNA sequencing}

Samples were identified by the 16 s rRNA gene sequencing using Sanger's method with automated Mega BACE 1000 sequencer (Amersham Biosciences-GE Healthcare, Little Chalfont, Buckinghamshire, UK) at Myleus Biotechonogy Facilities (Myleus, Belo Horizonte, Minas Gerais, Brazil). Primers $27 \mathrm{~F}$ and $1492 \mathrm{R}$ were used, according to Reysenbach, Longnecker and Kirshtein. The sequencing results were analysed using the Seq Scanner Software (Applied Biosystems, Foster City, California, USA) and the results were compared with database from NCBI and RDP with minimal percentage of $98 \%$ of similarity established for each identification sequence.

\section{Results}

From a total of 230 samples from silage, water, raw milk, endogenous starter culture and cheese, 88 Gram positive, catalase negative rods/cocci samples were pre-selected and then submitted to $16 \mathrm{~S}-23 \mathrm{~S}$ ITS amplification. The 16S-23S ITS showed 11 samples belonging to genus Streptococcus/ Lactococcus (12.5\%), 42 belonging to Enterococcus (47.7\%) and 35 belonging to Lactobacillus/Pediococcus (39.7\%). Genus distinction was performed based on methodology described by Nour 1998, Dobson et al. and Magalhães, Floresta and Moraes. Samples showing three different bands were submitted to rep-PCR (GTG) 5 reaction, and the results were expressed in the dendrogram shown in Figure 1. Samples were clustered in accordance to the results of Pearson correlation. One sample of each clustered group with similarity values over $90 \%$ was selected for 16S rRNA sequencing, in accordance to methodology described by Van Hoorde, Vandamme and Huys [6].

\section{Discussion}

LAB samples associated with raw milk are crucial elements that influence the quality, flavor, peculiarity and authenticity of cheeses. Several factors such as cattle feeding, milk composition, good manufacturing practices and environmental characteristics of the region may determine the diversity and dynamics of microbial communities associated with artisanal cheeses, as well as sensorial properties and the quality of the final product. As physical-chemical characteristics of the cheese are directly linked to the LAB activity, it is more than necessary to taxonomically stablish lineages and bacterial groups that could potentially contribute to enhance cheese sensorial aspects [6-8].

In the present study, L. plantarum, L. brevis, L. rhamnosus, $L$. paracasei e P. acidilactici were present in different sources and dairy farms. The L. plantarum specie was dominant alongside the entire fingerprinting analysis. In a study performed by Van Hoorde, Vandamme e Huys, L paracasei, Lactococcus lactis subsp. lactis, L. plantarum, Pediococcus pentosaceus, L. brevis, L. rhamnosus, L. curvatus, Enterococcus faecalis, Enterococcus durans L. perolens were identified by rep-PCR-(GTG5) and $16 \mathrm{~S}$ rRNA sequencing in traditional raw milk cheeses Bellie and Dulses. Pogacic et al. identified Lactobacillus rhamnosus,
Lactobacillus casei, Lactobacillus paracasei, Lactobacillus delbrueckii, Lactobacillus helveticus e Pediococcus acidilactici as predominant microbiota in Grana Padano cheese, also made with raw milk and endogenous starter culture, as predominant microbiota. As shown in Table 1, L. plantarum was identified in every source, except cheese with 28 days of ripening and silage, although it was the only species found in milk. This endorses the idea that L. plantarum is a predominant LAB in the region.

Regarding the Minas artisanal cheese, Borelli et al. found $L$ plantarum, $L$ casei, L brevis, L rhamnosus, Enterococcus faecalis, $P$ acidilactici and Weisella paramesenteroides throughout ripening time in Minas artisanal cheeses from Serra da Canastra region. Assessing LAB profile via DGGE in Minas artisanal cheeses from four distinct regions (Serro, Cerrado, Serra da Canastra and Araxá), Arcuri et al. [9] found Streptococcus salivarius, Streptococcus thermophilus, L plantarum and Lactococcus lactis as predominant microorganisms. At $65 \%$ of similarity, DGGE clustering showed a clear distinction between cheese LAB samples from different regions, although detecting low diversity regarding species-level. In the present study, low diversity regarding LAB samples was observed, but with a clear distinction in two major clusters at a higher similarity value (90\%), indicating greater divergences from subsequent lineages or samples.

LAB samples such as L. plantarum from certified dairy farms (A, B and C) were detected in the two major clusters, while noncertified dairy farms (D, E and F) showed samples restricted in a unique cluster. Even if the second major cluster showed higher diversity for species, much of this diversity derived of samples originated from certified dairy-farms. This indicates that these dairy farms may develop greater bacterial diversity regarding the environment in which the artisanal cheeses are produced, probably due to better manufacturer proceedings.

Pediococcus acidilaciti was isolated from cheeses originated from dairy farm $\mathrm{C}$ and dairy farm B, both presenting isolated clusters allocated in the second major cluster. Isolation and molecular identification of $\mathrm{P}$ acidilaciti in Minas artisanal cheeses was not yet related, although many studies had described the presence of this species in artisanal cheeses. Settanni and Moschetti [10] described interesting data regarding detection of L. paracasei, L. rhamnosus and P. acidilactici and their role as non-starter LAB (NSLAB), developing in advanced stages of cheese ripening. Thus, silage could possibly be acting as an NSLAB inoculator agent, which can be demonstrated with samples of silage and cheese with 28 days of ripening from dairy farm C, where L. paracasei was isolated. Although, more studies are necessary regarding the dynamic in microbial populations within these cheeses. According to Pogacic et al. [11], these NSLAB may represent only a small part of microbial populations in environments with high diversity such as milk and cheese, being hard to stablish solid evidence that extrapolates the concept of microbial community of these microorganisms. 
Samples of L. plantarum, L. paracasei and L. brevis were detected in water, milk, endogenous starter culture and, specifically L. plantarum, throughout many ripening stages in different dairy farms. This can be explained due to their role as NSLAB, developing in later stages of ripening regarding higher levels of proteolysis and development of flavor, as well as reducing pathogenic or spoiling microorganisms in cheeses [1219].

Detection of L. plantarum in endogenous starter culture can be compared to data from Poveda, Cabezas and Mc Sweeney, which consisted in inoculation of a starter culture of L. plantarum in Manchego cheeses. It was observed a higher concentrations of free amino acids in cheese curd with L. plantarum in contrast of cheeses made with a commercial starter culture. Terzic-
Vidojevic et al. identified that L. plantarm samples from raw milk artisanal goat cheese from Serbian showed important features in physical-chemical properties such as production of EPS and higher proteolytic activity, implying that this microorganism could be applied in starter cultures for cheese manufacturing.

\section{Conclusion}

Lactobacillus plantarum was the most abundant amongst other LAB, showing high similarity phylogenetically, despite its source. Certified dairy-farms showed high LAB diversity, probably due to good manufacturer proceedings. Water, silage and endogenous starter culture could act as disseminating agents in the environment and cheese, enhancing flavor sensorial aspects in the final product (Table 1).

Table 1: Distribution of LAB samples isolated from silage, water, endogenous starter culture, milk and cheeses from Campo das Vertentes region.

\begin{tabular}{|c|c|c|c|c|c|}
\hline \multirow{2}{*}{ Source } & \multicolumn{5}{|c|}{ Species } \\
\hline & L. Plantarum & L. paracasei & L. brevis & L. rhamnosus & P. acidilactici \\
\hline Cheese $0 \mathrm{~d}$ & D; F; G & & $\mathrm{C}$ & & \\
\hline Cheese 7d & $\mathrm{A} ; \mathrm{C}$ & & & & \\
\hline Cheese 14d & $A ; B ; C$ & & A & & \\
\hline Cheese 21d & $A ; C ; E$ & & & & \\
\hline Cheese 28d & & $\mathrm{C}$ & & & \\
\hline Cheese 60d & $\mathrm{A} ; \mathrm{B} ; \mathrm{D}$ & & & & \\
\hline Starter culture & $\mathrm{E} ; \mathrm{F}$ & & & & \\
\hline Silage & & & & B & B \\
\hline Water & D & & D & & \\
\hline Milk & D & & & & \\
\hline
\end{tabular}

\section{Acknowledgment}

We thank the Fundação de Amparo à Pesquisa de Minas Gerais (FAPEMIG) and Coordenação de Aperfeiçoamento de Pessoal de Nível Superior (CAPES) for funds and grants.

\section{References}

1. Castro RD, Oliveira LG, Sant Anna FM, Luiz LMP, Sandes SHC, et al. (2016) Lactic acid microbiota identification in water raw milk endogenous starter culture and fresh Minas artisanal cheese from the Campo das Vertentes region of Brazil during the dry and rainy seasons. J Dairy Sci 99: 6086-6096.

2. Standard, I D F (1988) Yogurt: Enumeration of characteristics microorganisms. International I D F Standard A 117.

3. Resende MFS, Costa HHS, Andrade EHP, Acurcio LB, Drummond AF, et al. (2011) Queijo-de-minas artesanal da Serra da Canastra: Influência da altitude das queijarias nas populações de bactérias ácido-lácticas. Arq Bras Med Vet Zoo 63: 1532-1538.

4. Mac Faddin JF (1980) Individual biochemical tests. In: Mac Faddin JF (Eds.), Biochemical Tests for Identification of Medical Bacteria. Philadelphia: Lippincott Williams and Wilkins, pp.1-320.

5. Tilsala-Timisjärvi A, Alatossava $T$ (1997) Development of oligonucleotide primers from the 16S-23S rRNA intergenic sequences for identifying different dairy and probiotic lactic acid bacteria by PCR. Int J Food Microb 35: 49-56.
6. Van Hoorde K, Vandamme P, Huys G (2008) Molecular identification and typing of lactic acid bacteria associated with the production of two artisanal raw milk cheeses. Dairy Sci Tech 88: 445-455.

7. Fortina MG, Ricci G, Acquati A, Zeppa G, Gandini A, et al. (2003) Genetic characterization of some lactic acid bacteria occurring in an artisanal protected denomination origin (PDO) Italian cheese, the Toma piemontese, Food Microb 20: 397- 404.

8. Moatsou G, Kandarakis I, Moschopoulou E, Anifantakis E, Alichanidis E (2001) Effect of technological parameters on the characteristics of kasseri cheese made from raw or pasteurized ewes' milk. International J Dairy Tech 54: 69-77.

9. Arcuri EF, Sheikha AF, Rychlik T, Piro-Métayer I, Montet D (2013) Determination of cheese origin by using 16S rDNA fingerprinting of bacteria communities by PCR-DGGE: Preliminary application to traditional Minas cheese. Food Control 30: 1-6.

10. Settanni L, Moschetti G (2010) Non-starter lactic acid bacteria used to improve cheese quality and provide health benefits. Food Microb 27: 691-697.

11. Pogacic T, Mancini A, Santarelli M, Bottari B, Lazzi C, et al. (2013) Diversity and dynamic of lactic acid bacteria strains during aging of a long ripened hard cheese produced from raw milk and undefined natural starter. Food Microb 36: 207-215.

12. Borelli BM, Ferreira EG, Lacerda ICA, Santos DA, Carmo LS, et al. (2006) Enterotoxigenic Staphylococcus spp. and other microbial contaminants during production of Canastra cheese. Braz J Microb 37: 545-550. 
13. Dobson CM, Deneer H, Lee S, Hemmingsen S, Glaze SS, et al. (2002) Phylogenetic analysis of the genus Pediococcus, including Pediococcus claussenii sp. nov., a novel lactic acid bacterium isolated from beer. Int J System Evolu Microb 52: 2003-2010.

14. Gevers D, Huys G and Swings J (2001) Applicability of rep-PCR fingerprinting for identification of Lactobacillus species. FEMS Microb Lett 27: 31-36.

15. Magalhães JT, Floresta F, Moraes CA (2005) Partial characterization of ribosomal operons of Lactobacillus delbrueckii UFV H2B20. Braz J Microb 36: 177-183.

16. Nour M (1998) 16S-23S and 23S-5S intergenic spacer regions of lactobacilli: nucleotide sequence, secondary structure and comparative analysis. Res Microb 149: 433-448.
17. Poveda JM, Cabezas L, Mc Sweeney PL (2004) Free amino acid content of Manchego cheese manufactured with different starter cultures and changes throughout ripening. Food Chem 84: 213-218.

18. Reysenbach AL, Longnecker K, Kirshtein J (2000) Novel bacterial and archaeal lineages from an in situ growth chamber deployed at a midatlantic ridge hydrothermal vent. Appl Env Microb 66: 3798-3806.

19. Steele J, Broadbent J, Kok J (2013) Perspectives on the contribution of lactic acid bacteria to cheese flavour development. Curr Op Biotec 24: 135-141.

\section{Your next submission with Juniper Publishers will reach you the below assets}

- Quality Editorial service

- Swift Peer Review

- Reprints availability

- E-prints Service

- Manuscript Podcast for convenient understanding

- Global attainment for your research

- Manuscript accessibility in different formats

( Pdf, E-pub, Full Text, Audio)

- Unceasing customer service

Track the below URL for one-step submission https://juniperpublishers.com/online-submission.php 